\title{
IDENTIFYING OPTIMAL LOCATION AND NECESSARY QUANTITY OF WAREHOUSES IN LOGISTIC SYSTEM USING A RADIATION THERAPY METHOD
}

\author{
Viktor DANCHUK ${ }^{1}$, Olena BAKULICH ${ }^{2}$, Vitaliy SVATKO $^{3 *}$ \\ ${ }^{1,3}$ Faculty of Transport and Information Technologies, National Transport University, Kyiv, Ukraine \\ ${ }^{2}$ Faculty of Management, Logistics and Tourism; National Transport University, Kyiv, Ukraine
}

Received 11 November 2016; revised 11 July 2017; accepted 1 November 2017

\begin{abstract}
The paper suggests a method for determining the optimal location of service points (warehouses) based on the method for optimal planning of radiation therapy of malignant tumors. This method enabled us to identify the location of the most optimal number of warehouses taking into account their capacity for the required volume of freight transportation and distance from warehouses to consumers. The results of the study coincide with the results obtained by using the method of ant algorithm. The proposed method of finding the optimal location of warehouses enables to significantly minimize the cost of delivering goods from a producer to a consumer.
\end{abstract}

Keywords: warehouse, supermarket, routing task, small-lot freight, optimal route, optimization, freight transportation, logistics.

\section{Notations}

$G \quad-$ is limited area of service in $k$-dimensional space $R$;

$\tau_{i} \quad-$ the sources of influence on the environment;

$d_{i}\left(r_{i}\right)$ - function the influence of each $i$-source at the point $x \in G$;

$D(\tau, x)$ - function forms a field of action;

$Q_{i} \quad$ - the intensity (power) of $i$-source;

$\alpha_{i}>0-$ is the function parameter showing how "wide" the performance of the source $\tau_{i}$;

$W \quad$ - the volume of the work performed;

$G_{f r} \quad$ - is freight weight;

$S_{f r} \quad-$ is mileage with a freight.

\section{Introduction}

Currently, there is a lot of competition in transportation market. As a result, the optimization of freight transportation is of great importance. Today much of the road transportation accounts for small-lot freight when the size of the consignment sent or received is much smaller than load capacity of the vehicle. In this regard, for companies providing delivery services the optimal route and optimal location of the warehouse are decisive items.
Finding the optimal location of infrastructure objects solves multiple problems at once. On the one hand, the density of large cities does not allow a large number of sites to be used for the construction of warehouses and freight transhipment points. On the other hand, the suppliers are interested in reducing the number of such warehouses through the optimal location of the existing ones. In addition, in determining the optimal location of the warehouse customers' needs should also be taken into account. Therefore, among the conditions that must be considered when determining the optimal location of the warehouse are the volume of customers' needs, the capacity of warehouses, and load capacity of vehicles engaged in distribution of goods. Existing methods do not always enable us to fully meet the challenge of transportation logistics.

Based on the above, the development and improvement of the current methods for the optimal location of warehouses with allowance made for their capacity, the number of consumers, the required volume of freight transportation and distances from warehouses to consumers are still topical.

*Corresponding author. E-mail: vitaliy_svatko@ukr.net 
Many scientific papers focus on the issues of finding the optimal location of infrastructure objects. A review of main methods for optimal location of objects is proposed by Drezner (2014). The paper deals with the classification of widely used methods for optimal location of objects on a network. Among them there are such methods as generalized Weiszfeld, "the big triangle, small triangle", etc. The suggested methods allow us to determine both one and several objects of optimal location. It is achieved through applying iteration procedure. A brief description, the relationship between the methods, advantages and disadvantages, and the scope of application are given in the paper. The advantages of these methods are their focus on the specific group of tasks, which in its turn makes it possible to obtain the results of high accuracy. Among the disadvantages of the suggested methods is that none of them is universal and does not meet all the requirements and demands of the market. In addition, an extremely large number of factors that must be included in the calculations can be regarded as the disadvantage.

Sun (2006) the problem of finding the optimal location of objects on a network is solved with the help of tabu search. This method of finding the optimal location of objects consists in the phased finding of an optimal solution and comparing it with a previously found one. The speed of calculations and high accuracy of found results is one of the advantages of the method whereas the impossibility of simultaneously finding the optimal location of several objects on a network is one of its disadvantages.

Kazakov and Lempert (2011) is proposed to solve the problem of optimal location of objects using "wave" method, based on the analogy between the location of global extremum of integrated functional and distribution of light in an optical heterogeneous environment.

Solving the problem of the optimal location of objects of various natures is the subject of research in different fields. In papers by $\mathrm{Gu}$ et al. (2010) and Griffin et al. (2008) examines ways and methods optimization for solving the problem of optimal location for companies providing preventive health services, so-called community health centers. For instance, paper $\mathrm{Gu}$ et al. (2010) proposes a new methodology for finding the optimal location of the preventive health service center, employing the algorithm Interchange. Among the factors taken into account in calculations are distance from patients to the service center, the number of patients and medical care requests, their diseases and etc. Griffin et al. (2008) suggests the optimization model, which is designed to determine the best location, the number of medical healthcare service centers and the capacity of these enterprises. Thus, when determining the location of such facilities, the authors minimize fixed and variable costs for upkeep and maintenance of centers. The location optimization model of centers proposed by Griffin et al. (2008) can reduce costs and increase service quality by $20 \%$ on average.

The problems of optimal location of objects and resources have features that must be taken in consideration when formalizing such tasks and developing algorithms for accomplishing them. Sonmez and Lim (2012) present an analysis of currently existing algorithms for solving problems of optimal location of objects on the transportation network as well as their classification and algorithm solution. Sonmez and Lim (2012) also proposed the model of optimal location of objects whose location can change when modifying set conditions. The model makes it possible to change the location of infrastructure in the future, abandoning previously defined and finding new optimal locations without increasing set costs.

The strategic planning of a supply network to customers is emphasized by Melo et al. (2006). As a part of the proposed mathematical model, the task of planning the location of objects aimed at serving customers is accomplished. Besides, the possibility of changing previously found optimal solutions is provided through modifying the information on costumers needs. The grave disadvantage of the mathematical model is that it enables us to solely find an optimal solution to the tasks of only small dimension.

Taji et al. (2008) considers the problem of the optimal location of structures in the city, such as a railway station system. In the paper by Taji et al. (2008), the model is presented as a tree whose vertices are railway stations and whose edges are lines connecting respective stations. The problem is to find the railway station location, and create a route, which is minimal for passengers. The authors proposed a heuristic algorithm, which is divided into two stages. At the first stage, it determines the initial position of objects while at the second it reveals the most optimal location. The algorithm is executed until the optimal location of objects is found.

The method of optimal location of the basic container terminal based on the method of dichotomy is proposed by Kazakov and Pospelov (2008). It is suggested to apply this method for the optimal location of a warehouse.

Therefore, the results of the literature sources analysis shows that there are currently no methods, which enable us to fully solve the problem of multivariable process optimization of transport logistics. In this respect, it is still topical to develop optimization techniques, which are based on the methods used to describe the processes of another physical nature. Hence, in our opinion, applying the method for planning of radiation therapy of malignant tumors might be promising Klepper (2009) and Grankina (2014). Klepper (2009) solves the problem of optimal planning of radiation therapy of malignant tumors in which it is necessary to allocate a specified number of radiation sources within the damaged area so that the cumulative effect of sources is as homogeneous as possible. The modification of the model presented by Klepper (2009) and proposed by Grankina (2014) using the elements of the theory of continuous task theory of optimal set partitioning.

With the aim to further develop the methodology for optimizing the location of warehouses and routing pro- 
cesses of freight transportation, the paper suggests the intelligent method for solving such kind of problems. It is based on the method for optimal planning of radiation therapy of malignant tumors Klepper (2009) and its modification Grankina (2014).

\section{Employing the method for optimal planning of radiation therapy of malignant tumors for solving the problems of the optimal location of warehouses}

\subsection{A background: the method for optimal planning of radiation therapy of malignant tumors}

According to Klepper (2009) in the problem of optimal planning of radiation therapy of malignant tumors, it is necessary to allocate a specified number of radiation sources within the damaged area. In the interstitial radiation therapy to achieve full therapeutic effect (tumor disease-free recovery), it is essential to place radiation sources in the tumor in such a way that its dose field should be as homogeneous as possible. The point is that at low levels of radiation (in local minima field of influence) there is a relapse possibility, and vice versa, in the high-dose radiation there might be radiation necrosis, which are treated with difficulty.

Therefore, the problem will be interpreted as follows: "field service" is affected area of the body whose cells are "customers", and "service points" are the sources of radiation placed inside the affected area, creating therapeutic radiation field neutralizing lesions. Besides, we assume that lesions in different parts of the skin may be different. The problem is to place a specific number of radiation sources in such a way that dose field (cumulative effect of sources) is as homogeneous as possible.

Let $G$ be a limited area of service in $k$-dimensional space $R$, points of which are labelled as $x$. Let us denote $\tau_{i}=\left(\tau_{i}^{1}, \ldots, \tau_{i}^{n}\right) \in G, i=\overline{1, N}$ the sources of influence on the environment, which should be placed. Let the influence of each $i$-source at the point $x \in G$ is described by the function $d_{i}\left(r_{i}\right)=d_{i}\left(\left\|x-\tau_{i}\right\|\right), i=\overline{1, N}$ where $\|$.$\| is the Euclid-$ ean norm. The combined effect of all sources $\tau_{i}, i=\overline{1, N}$ at the point $x \in G$ forms a field of action $D(\tau, x)$, described by the function Klepper (2009):

$$
D(\tau, x)=\sum_{i=1}^{N} d_{i}\left(\left\|x-\tau_{i}\right\|\right) .
$$

It $\tau_{i}, i=\overline{1, N}$ should be placed in such a way that it minimizes the level of field $D(\tau, x)$ in this area $G$ as much as possible. In other words, it is necessary to place the sources so that the field throughout the area $G$ is as homogeneous as possible. Mathematically, this requirement is written as follows:

$$
\min _{x \in G} D(\tau, x) \rightarrow \max _{\tau \in G^{N}}
$$

Unlike the model Klepper (2009), where the function of source influence $d_{i}\left(r_{i}\right)$ was chosen as a power function $d_{i}\left(r_{i}\right)=\frac{1}{r_{i}^{\theta}}$, when $\theta=2$, the paper, according to Grankina (2014), proposes to consider the following function:

$$
d_{i}\left(r_{i}\right)=Q_{i} \cdot \exp \left(-\alpha_{i} \cdot r_{i}\right),
$$

where: $Q_{i}$ is the intensity (power) of $i$-source; $\alpha_{i}>0$ is the function parameter showing how "wide" the performance of the source $\tau_{i}$ is (it is selected experimentally); $r_{i}=\left\|x-\tau_{i}\right\|, i=\overline{1, N}$. A choice of the type of the function of source influence is based on the following considerations. Power functions of type $d(r)=\frac{1}{r^{\theta}}, \theta>0$ meeting the condition $d_{i}(+0)=\infty$ have an unpleasant feature that requires the removal of these points when calculating the function (1) implementing the algorithm for solving the task Grankina (2014). This greatly complicates or makes almost impossible to use maximization of numerical methods that worked well even in solving problems of undifferentiated optimization, the convergence of which is theoretically proved. The function of the (3) type is devoid of such disadvantages.

\subsection{Employing the method for optimal planning of radiation therapy of malignant tumors for solving the problems of the optimal location of warehouses}

The proposed method in Klepper (2009) and Grankina (2014) solves the problem of the optimal location of radiation sources of malignant tumors inside the damaged area so that the cumulative effect of sources is as homogeneous as possible. From another point of view, this method can be employed to solve the problem of the optimal location of infrastructure objects such as warehouses, shops, repair shops, first-aid stations, etc. In this context, the problem of the optimal location lies in bringing the objects of infrastructure nearer to a consumer. In our case, we will regard infrastructure objects as warehouses, and consumers as supermarkets. Limited area $G$ is a service field whose points are supermarkets while infrastructure objects are warehouses, which are located inside limited area $G$. The problem consists in locating warehouses closest to supermarkets.

Let the limited area of service $G$ have limited $n$ set of delivery points (warehouses) - $\left(A_{1}, A_{2}, \ldots, A_{i}, \ldots, A_{n}\right)$, in which there is the same cargo in the quantity of $a_{1}, a_{2}, \ldots, a_{i}, \ldots, a_{n}$ units. The total volume of $n$ warehouses $a$ makes up:

$$
a=\sum_{i=1}^{n} a_{i} .
$$

On the other hand, we have a limited service area $G$ with $m$ limited set of customers (supermarkets) $\left(B_{1}, B_{2}, \ldots, B_{j}, \ldots, B_{m}\right)$, whose demand is $b_{1}, b_{2}, \ldots, b_{j}, \ldots, b_{m}$ units, respectively. While the total volume of demand for goods is: 


$$
b=\sum_{j=1}^{m} b_{j} .
$$

We believe that the transportation from each supply point to each consumption point is possible. $C_{j}$ denotes the total transportation costs associated with shipping freight unit from the point of delivery $A_{i}$ to consumers $B_{j}(i=1, n ; j=1, m)$. The influence of each $i$-warehouse at the point $x \in G$ is described by function (3).

Each warehouse is characterized by the location with coordinates $\left(x_{i}, y_{i}\right)$ and the distance to each consumer (supermarket) as well as the maximum capacity (the amount of cargo that can be stored at this facility). Each buyer is characterized by the location coordinates $\left(x_{j}, y_{j}\right)$, the distances to each supplier and the size of demand (the volume of delivered product). The task lies in locating warehouses for a specific number of customers in such a way that they are situated most optimally to suppliers (i.e. as close as possible to them). That means that it is necessary to opt for warehouses from existing ones $\left(A_{1}, A_{2}, \ldots, A_{i}, \ldots, A_{n}\right)$ whose total transportation costs $C_{i j}$ for goods delivery to all consumers will be minimal.

Initially, we find the optimally located (closest) to all consumers for existing $n$ warehouses. At the same time we presume that the found warehouse is of such a capacity, which can meet all the demands of consumers. The calculation uses such an exponent as $Q_{i}$ - intensity (power) of $i$-source (see Section 2.1). In our case the value of this exponent is determined by inversely proportional to the value of work performed during cargo transportation from a certain warehouse to all consumers. The size of transport work performed is determined by formula $W$ :

$$
W=G_{f r} \cdot S_{f r},
$$

where: $G_{f r}$ - is cargo weight; $S_{f r}$ - is mileage with freight.

Function parameter $\alpha_{i}$, which shows how wide the effect of source $\tau_{i}$ is, is selected experimentally. In our case $\alpha_{i}$ is determined as 0.2 .

Therefore, using the algorithm for solving the optimization problem (1)-(6) allows us to find the optimal location of the warehouse, which completely meets the needs of all consumers. Let it be warehouse $A_{t}$ whose capacity is $a_{t}$ units.

However, we know that when planning the location of warehouses to meet the needs of consumers in a metropolis, there is often a situation when the capacity of one warehouse makes it impossible to fully meet the needs of all customers (supermarkets) in a limited area of service.

Then we take the case when the capacity of warehouse $A_{t}$ does not satisfy the total demand for the goods of the volume $b$. We choose the minimal distance between two respective objects as a criterion, which will be used to find consumers served by optimally found warehouse $A_{t}$. Thus, this warehouse will serve only those consumers, which are at the minimal distance from it, and its total capacity will not exceed the consumers' demand.
Let warehouse $A_{t}$ completely meet the demand for goods of $k$-consumers from the set $\left\{B_{m}\right\}_{i}$ with total value:

$$
Y=\sum_{l=1}^{k} y_{l},
$$

where: $\left(y_{1}, y_{2}, \ldots, y_{k}\right)$ is the individual demand of $k$-consumers. At the same time:

$$
a_{t}=Y, k<m \text {. }
$$

As the optimally found warehouse with its capacity completely satisfies the condition (8), there is a need to find an additional warehouse to meet the demand of other consumers. Again, the next optimal warehouse $A_{t}$ for delivering goods to consumers is found through algorithm (1)-(6). Now, we consider the set $\left\{A_{n-1}\right\}$ in which warehouse $A_{t}$ with the capacity $a_{t}$ is not included and the set $\left\{B_{m-k}\right\}$ in which $k$-consumers with the demand according to (7) is not included too.

If as a result of the optimization, the next found warehouse satisfies the conditions in formula (8), then the procedure (1)-(6) is repeated until the number of optimal warehouses $S$ with total capacity $Y S$ is found, which satisfies the condition $Y S=b$.

\section{Case study: solving the problem of the optimal location of warehouses using the method of radiation therapy}

Since the problem of optimizing road light freight transportation in megacities has been especially topical over the recent years, we deem that short shelf life food delivery from a producer to a consumer is the most representative variant of such kind of shipment. The problem of road light freight transportation is typical of densely populated cities, which, in its turn, are characterized by congested transport networks, high density of traffic and a large number of customers (supermarkets). A plot of land in Kyiv, which is shown in Figure 1, was selected as an example for solving the problem of the optimization, using the proposed method.

As shown in Figure 1, a certain section of Kyiv has a network of supermarkets (buyers) who are customers with a certain volume of demand for goods. In addition, the warehouse of the supplier with a certain amount of places for storing goods, as well as the main warehouse of the manufacturer located on the territory of the enterprise is located on the specified site. Since our system includes the main manufacturer, distribution centers and end users (supermarkets), we can talk about the classic model of the logistics system. The schematic representation of the model of the logistic system is shown in Figure 2.

Let us have as output data in this area of the territory of 5 warehouses (distribution centers) and warehouse in the territory of the manufacturer of products. Each warehouse is characterized by location (coordinates), the distance to each customer (supermarket) and a maximum capacity (the amount of cargo that can be stored at this facility). 


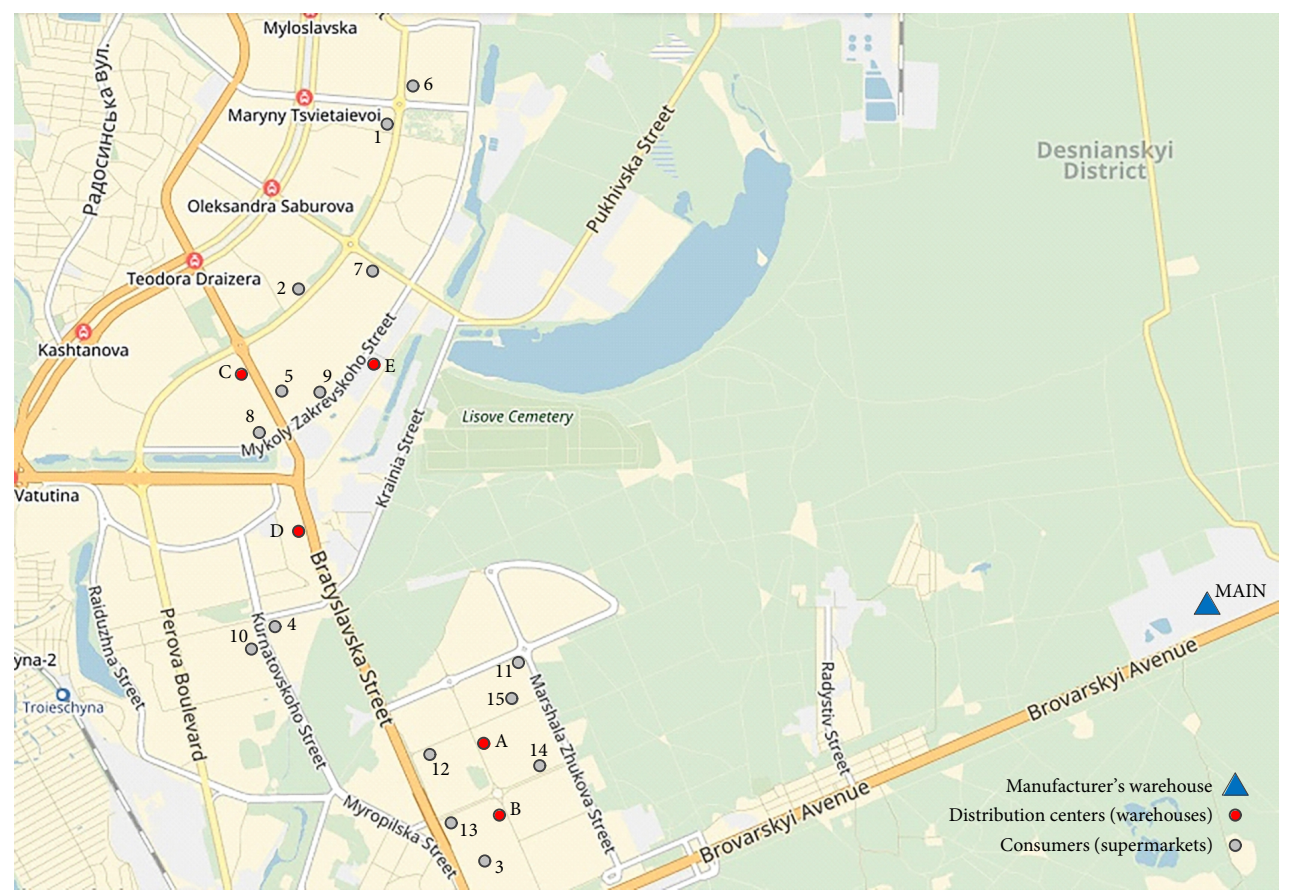

Figure 1. The location of warehouses and supermarkets in Kyiv

a)

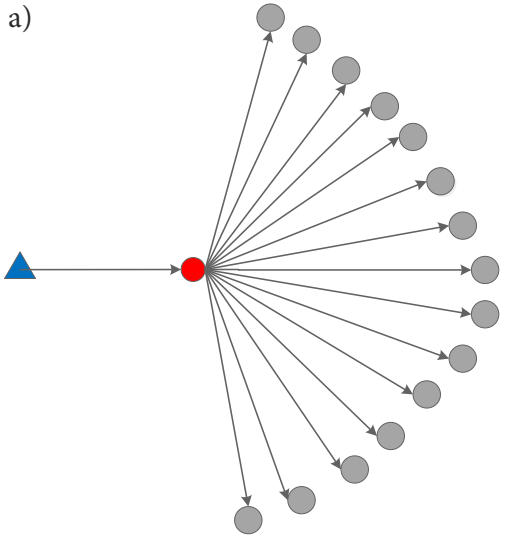

b)

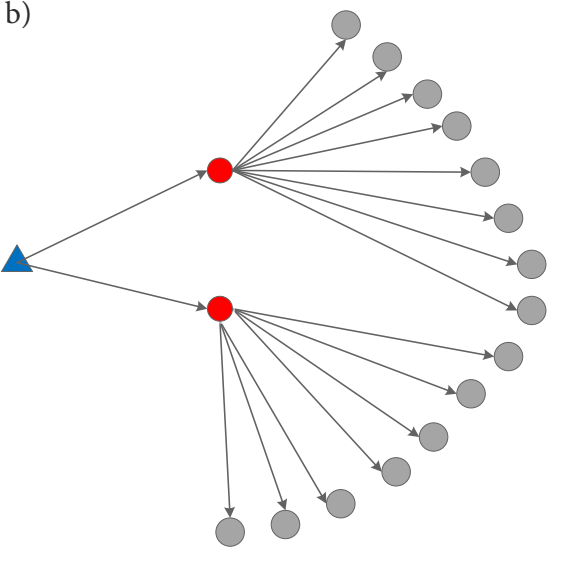

c)

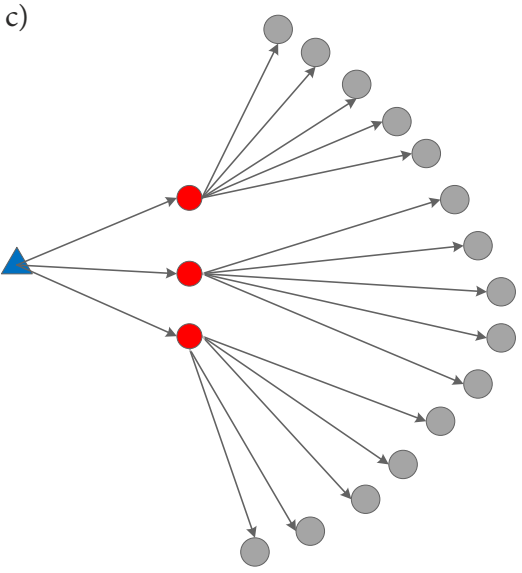

Manufacture's warehouse

Distribution centers (warehouses)

Consumers (supermarkets)

Figure 2. The physical model of the distribution system will supply products: a - with one distribution center; $\mathrm{b}$ - with two distribution centers; c - with three distribution centers

In addition, there are 15 customers (in this case they are supermarkets). Data on consumers' demand (supermarkets) and the capacity of suppliers (warehouses) shown in Table 1. Delivery of goods is carried out according to the scheme of the main manufacturer - distribution centers - supermarkets.

The information about the distance between customers and warehouses as well as the weight of freight is shown in Table 2.

In determining the total cost of delivery of goods in the logistics system, the following groups of costs are taken into account: transport costs, expenses for driver's labour, costs associated with storage of goods, operating costs and other costs, as well as costs from lost sales.
In determining the optimal location of the warehouse in the logistics distribution system, the total cost of delivering goods from the manufacturer to the consumer is divided into two parts: the cost of delivering goods from the manufacturer to distribution centers and the cost of delivering goods from distribution centers to end consumers (supermarkets).

Considering the costs in this form, in our opinion, will enable the complex solution of the problem of finding the optimal location of the warehouse, for the entire system of distributed logistics.

Using formulae (1)-(6), we found an optimally located warehouse among existing ones to consumers. That is warehouse A. 
Table 1. Customers' demand and suppliers' capacity

\begin{tabular}{|c|c|c|c|c|}
\hline No & Marking & Type of object & Address & Weight $^{*}[\mathrm{~kg}]$ \\
\hline 1 & MAIN & warehouse & Brovarsky avenue, $16 \mathrm{~km}$ & 45000 \\
\hline 2 & $\mathrm{~A}$ & warehouse & Milyutenko street, 28 & 8000 \\
\hline 3 & B & warehouse & Milyutenko street, 10B & 8000 \\
\hline 4 & $\mathrm{C}$ & warehouse & Theodore Dreiser street, 11 & 9000 \\
\hline 5 & $\mathrm{D}$ & warehouse & Karbyshev street, 18B & 5000 \\
\hline 6 & E & warehouse & M. Zakrevskiy street, 20 & 8000 \\
\hline 7 & 1 & supermarket & Mayakovskiy avenue, 85 & 1200 \\
\hline 8 & 2 & supermarket & Mayakovskiy avenue, $43 / 2$ & 700 \\
\hline 9 & 3 & supermarket & Bratyslavska street, 14B & 1500 \\
\hline 10 & 4 & supermarket & Stal'skiy street, $22 / 10$ & 1900 \\
\hline 11 & 5 & supermarket & Theodore Dreiser street, 8 & 900 \\
\hline 12 & 6 & supermarket & Mayakovskiy avenue, 60/10 & 2200 \\
\hline 13 & 7 & supermarket & Saburov street, 3 & 1100 \\
\hline 14 & 8 & supermarket & M. Zakrevskiy street, 21 & 1500 \\
\hline 15 & 9 & supermarket & M. Zakrevskiy street, 29 & 600 \\
\hline 16 & 10 & supermarket & Kurnatovskiy street, 11 & 850 \\
\hline 17 & 11 & supermarket & Lisoviy avenue, 28 & 1300 \\
\hline 18 & 12 & supermarket & Academician Kurchatov street, 8a & 1900 \\
\hline 19 & 13 & supermarket & Sholem Aleichem street, 4 & 750 \\
\hline 20 & 14 & supermarket & Sholem Aleichem street, 17 & 500 \\
\hline 21 & 15 & supermarket & Academician Kurchatov street, 23 & 1550 \\
\hline
\end{tabular}

Note: ${ }^{*}$ - in the field Weight there is capacity for warehouse while there is freight demand for supermarkets.

Table 2. Matrix of distance between warehouses and supermarkets, demand for freight weight and the volume of the work performed

\begin{tabular}{|c|c|c|c|c|c|c|c|c|c|c|c|}
\hline \multirow[b]{2}{*}{ 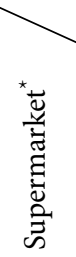 } & \multirow{2}{*}{ 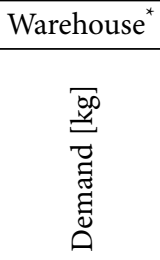 } & \multicolumn{2}{|c|}{ A } & \multicolumn{2}{|c|}{ B } & \multicolumn{2}{|c|}{$\mathrm{C}$} & \multicolumn{2}{|c|}{$\mathrm{D}$} & \multicolumn{2}{|c|}{ E } \\
\hline & & 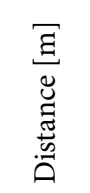 & 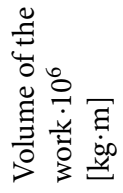 & 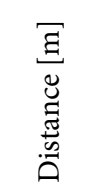 & 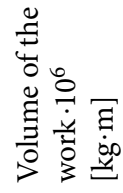 & 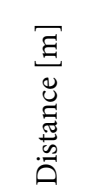 & 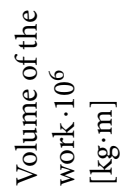 & 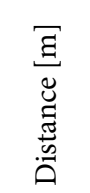 & 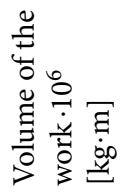 & 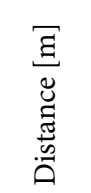 & 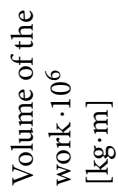 \\
\hline 1 & 1200 & 7600 & 9.12 & 9600 & 11.52 & 4000 & 4.8 & 5000 & 6 & 5500 & 6.6 \\
\hline 2 & 700 & 6700 & 4.69 & 8700 & 6.09 & 3100 & 2.17 & 4200 & 2.94 & 4700 & 3.29 \\
\hline 3 & 1500 & 2600 & 3.9 & 2100 & 3.15 & 6600 & 9.9 & 6300 & 9.45 & 6900 & 10.35 \\
\hline 4 & 1900 & 3000 & 5.7 & 5000 & 9.5 & 2600 & 4.94 & 1600 & 3.04 & 3000 & 5.7 \\
\hline 5 & 900 & 4400 & 3.96 & 6400 & 5.76 & 600 & 0.54 & 1900 & 1.71 & 2400 & 2.16 \\
\hline 6 & 2200 & 7500 & 16.5 & 9500 & 20.9 & 4000 & 8.8 & 5000 & 11 & 5500 & 12.1 \\
\hline 7 & 1100 & 6200 & 6.82 & 8200 & 9.02 & 2600 & 2.86 & 3700 & 4.07 & 4100 & 4.51 \\
\hline 8 & 1500 & 4300 & 6.45 & 6300 & 9.45 & 1100 & 1.65 & 1800 & 2.7 & 2300 & 3.45 \\
\hline 9 & 600 & 4300 & 2.58 & 6300 & 3.78 & 1100 & 0.66 & 1800 & 1.08 & 2200 & 1.32 \\
\hline 10 & 850 & 4900 & 4.165 & 6400 & 5.44 & 4200 & 3.57 & 3100 & 2.635 & 4500 & 3.825 \\
\hline 11 & 1300 & 1300 & 1.69 & 4000 & 5.2 & 4300 & 5.59 & 4100 & 5.33 & 4700 & 6.11 \\
\hline 12 & 1900 & 1400 & 2.66 & 2900 & 5.51 & 4600 & 8.74 & 4300 & 8.17 & 4900 & 9.31 \\
\hline 13 & 750 & 1200 & 0.9 & 2600 & 1.95 & 4400 & 3.3 & 4100 & 3.075 & 4700 & 3.525 \\
\hline 14 & 500 & 1200 & 0.6 & 1800 & 0.9 & 5500 & 2.75 & 5300 & 2.65 & 5900 & 2.95 \\
\hline 15 & 1550 & 900 & 1.395 & 2300 & 3.565 & 5000 & 7.75 & 4800 & 7.44 & 5300 & 8.215 \\
\hline Total & 18450 & 57500 & 71.13 & 82100 & 101.7 & 53700 & 68 & 57000 & 71.3 & 66600 & 83.4 \\
\hline
\end{tabular}

Note: ${ }^{*}$ - addresses (markings) of supermarkets (warehouses) are given in Table 1. 
Since the capacity of the determined warehouse A is much less $(8000 \mathrm{~kg})$ than the demand of all customers $(18450 \mathrm{~kg})$, there is a need to identify those supermarkets that will be served by the determined warehouse A. The minimum distance between objects is the criterion by which we determine such customers (see Section 2.2). Thus, the determined optimal warehouse will serve those customers who are at the minimum distance.

Employing this mechanism for determining the supermarkets, it was calculated that warehouse A (Milyutenko street, 28) with a capacity of $8000 \mathrm{~kg}$ units of freight will be able to serve supermarkets in Academician Kurchatov street, $23(1550 \mathrm{~kg})$, Sholem Aleichem street, $17(500 \mathrm{~kg})$, Sholem Aleichem street, $4(750 \mathrm{~kg})$, Lisoviy avenue, $28(1300 \mathrm{~kg})$, Academician Kurchatov street, $8 a(1900 \mathrm{~kg})$ and Bratyslavska street, $14 B(1500 \mathrm{~kg})$. The total demand of these supermarkets is $7500 \mathrm{~kg}$ units of freight that does not exceed possibilities of a specified warehouse.

As the found optimal warehouse with its capacity cannot meet the demands of all the customers, according to formula (8) there is a need to find another warehouse to meet the demands of supermarkets, which were not included in the initial distribution of goods.

Using formulae (1)-(6) we find a new optimal warehouse for the group of customers. Previously found optimal warehouse A (Milyutenko street, 28) and customers located in Academician Kurchatov street, 23, Sholem Aleichem street, 17, Sholem Aleichem street, 4, Lisoviy avenue, 28, Academician Kurchatov street, $8 a$ and Bratyslavska street, $14 \mathrm{~B}$ are excluded from the calculation. The calculation results indicate that for those customers who remain unused the most optimal warehouse is warehouse D located in Karbyshev street, $18 B$ with a capacity of $5000 \mathrm{~kg}$ units of freight. Since the capacity of the determined warehouse does not meet the demands of customers, there is a need to identify those supermarkets that will be served by the determined warehouse. Applying the mechanism described above, we find supermarkets that are located closest to the specified warehouse. Warehouse D capacity allows us to satisfy the demands of these customers: Stal'skiy street, 22/10 (1900 kg), M. Zakrevskiy street, 21 $(1500 \mathrm{~kg})$, M. Zakrevskiy street, $29(600 \mathrm{~kg})$ and Theodore Dreiser street, $8(900 \mathrm{~kg})$. The total demand of these supermarkets is $4900 \mathrm{~kg}$ units of freight that does not exceed possibilities of a specified warehouse $\mathrm{D}$.

Therefore, as the found optimal warehouses with their capacity cannot meet the demands of all consumers, there is a need to continue finding another warehouse to satisfy customers' demands. Using formulae (1)-(6) we find a new optimal warehouse for the group of customers. Previously used warehouses and supermarkets are excluded from the calculation. According to the calculations, the optimal warehouse is warehouse $\mathrm{C}$ located at Theodore Dreiser street, 11 with a capacity of $9000 \mathrm{~kg}$ units of freight. The capacity of the warehouse makes it possible to serve all supermarkets remaining in the following addresses: Mayakovskiy avenue, 85 (1200 kg), Mayakovskiy avenue, 43/2 (700 kg), Kurnatovskiy street, $11(850 \mathrm{~kg})$,
Mayakovskiy avenue, 60/10 (2200 kg) and Saburov street, 3 $(1100 \mathrm{~kg})$. The total demand of these supermarkets is 6050 $\mathrm{kg}$ units of freight that does not exceed possibilities of a specified warehouse $\mathrm{C}$.

After determining the optimal location and quantity of warehouses, it is necessary to create an optimal route for distributing goods from a warehouse to customers. To determine the optimal route of goods delivery from a warehouse to customers, the ant-colony method was used, as described in Dorigo et al. (1996) and Shtovba (2003). As there were (formulae (1)-(8)) 3 warehouses previously determined for the distribution of goods then there will be 3 delivery routes. Employing the ant-colony method given in Dorigo et al. (1996) and Shtovba (2003), the following optimum (minimum) delivery routes were created:

- route No $1: \mathrm{A} \rightarrow 15 \rightarrow 11 \rightarrow 14 \rightarrow 13 \rightarrow 3 \rightarrow 12 \rightarrow \mathrm{A}$ (route length is $8400 \mathrm{~m}$ );

- route No 2: D $\rightarrow 4 \rightarrow 9 \rightarrow 5 \rightarrow 8 \rightarrow \mathrm{D}$ (route length is $7600 \mathrm{~m}$ );

- route No 3: $\mathrm{C} \rightarrow 6 \rightarrow 1 \rightarrow 7 \rightarrow 2 \rightarrow 10 \rightarrow \mathrm{C}$ (route length is $19400 \mathrm{~m}$ ).

Figure 3 show the layout of warehouses and supermarkets location, delivery routes from specified warehouses to customers.

After finding both the optimal location of the warehouses and their number by using the ant algorithm, the optimum (minimum) routes of goods delivery from distribution centers (warehouses) to consumers were created.

\section{Results and discussion}

To check the accuracy of the applied method for optimizing the location of warehouses within transport logistics, the ant-colony method Dorigo et al. (1996) and Shtovba (2003), which enabled us to create the optimal goods delivery route from a warehouse to a customer as a part of traveling salesman problem.

To do this, consider the same model problem as in Section 3. In this task, there is a main warehouse located on the territory of the manufacturer of products, 5 distribution centers (warehouses) and 15 supermarkets. It is necessary to determine from those warehouses the total cost of delivery of goods from which to consumers will be minimal. Costs for the delivery of goods are divided into two groups: (1) from the main warehouse of the manufacturer to the distributed centers and (2) from the distributed centers to the supermarkets. The total cost of delivery of goods includes transport costs, driver's expenses, costs associated with storage of goods, operating costs and other costs, as well as costs from lost sales. Thus, we consider the optimal location that composition, the cost of delivery of goods to all consumers will be minimal.

With the help of ant-algorithm method for each of 5 warehouses, we find the shortest route of goods delivery to all 15 supermarkets. Using the data on the distance between the warehouses and supermarkets as well as the demand for cargo of each supermarket, shown in Tables 1 and 2, we calculate the volume of the transport work performed on each route. 
a)

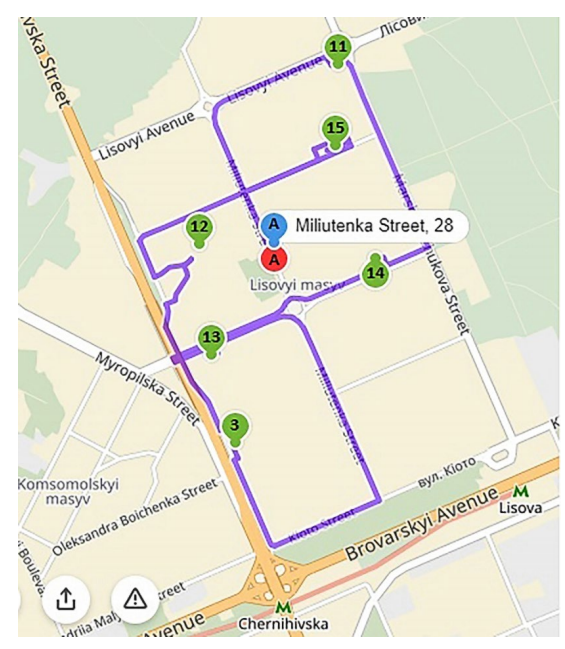

b)

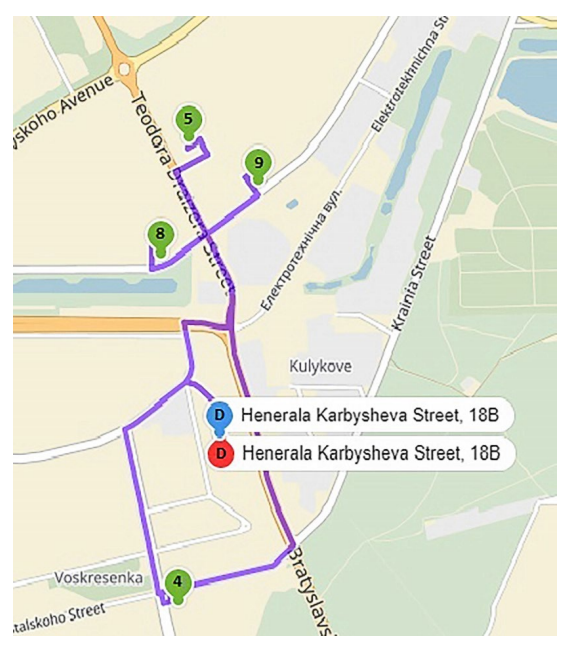

c)

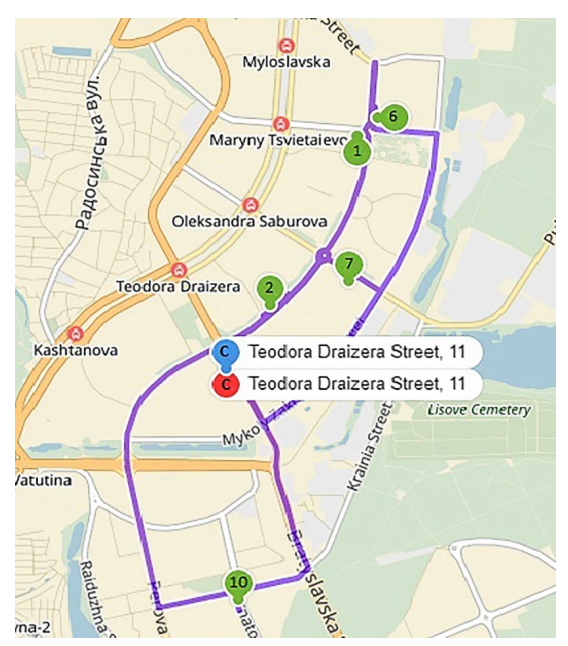

Figure 3. Goods delivery routes: a - route No $1 ; \mathrm{b}$ - route No 2; c - route No 3

As the weight of the load in the model problem is 18450 $\mathrm{kg}$, for transportation vehicles models used MAN TGA $(20000 \mathrm{~kg})$ truck. For this vehicle fuel consumption data have been established by company. They are as follows: fuel consumption per unit distance $-30 \cdot 10^{-8} \mathrm{~m}^{3} / \mathrm{m}$; fuel consumption per unit performance (transported tons of freight) $-1 \cdot 10^{-11} \mathrm{~m}^{3} / \mathrm{kg} \cdot \mathrm{m}$, fuel consumption for the operation of the refrigerator $4 \cdot 10^{-11} \mathrm{~m}^{3} / \mathrm{kg} \cdot \mathrm{m}$, type of fuel "diesel". The average cost of such fuel in the city of Kyiv in 2017 is $22.10 \cdot 10^{3} \mathrm{UAH} / \mathrm{m}^{3}$.

Employing the data on fuel cost for the chosen model of transport vehicle and the average cost of fuel in the market, we calculate the total expenditure on the goods delivery from each warehouse to all the consumers.

In determining the optimal location of the distributed center, an important role in the total amount of expenses is played by the driver's labour costs. According to statistics (Ua.trud.com 2017), the average wage of a truck driver in the city of Kyiv in April 2017 is UAH 10000. The standard of working hours for a five-day 40-hour working week in April 2017 is 152 hours (MSP 2017). The hourly wages of the driver are established at the enterprise that carries out the product outlet. The cost of 1 hour of the driver's work in April 2017 is 65.79 UAH. The duties of the driver include only the registration of documents, the dispatch of goods by destination and control over compliance with the rules of loading/unloading and acceptance/delivery of cargo. Thus, the time spent by the driver includes: the time of loading or unloading the goods; time for document processing; time of delivery of goods (time for route passing between points); manoeuvring time. Normative data for finding the time for each type of work is given in the only time limits for the carriage of goods by road and lump-sum charges for the payment of drivers (VRU 1987). In order to calculate the time of delivery of goods, the average speed of traffic in the city of Kyiv was taken $25 \mathrm{~km} / \mathrm{h}$. The results of the calculations are presented in Table 3.
It should be noted that in our model problem only the driver's option is considered in the framework of his normal working day, which does not involve working out overnight, evening, night or holiday hours.

As can be seen from the calculation results, shown in Table 3, the warehouse at Milyutenko street, 28, are most optimally situated out of the 5 proposed ones. The cost of delivery from the aforementioned warehouse is minimal and equals 1564.30 UAH. The highest cost of goods delivery from the warehouse, which is located at M. Zakrevskiy street, 20, is 1678.02 UAH. In the paper, applying method of radiation therapy, we determined warehouse $\mathrm{A}$, which is at Milyutenko street, 28, as most optimally located to all the supermarkets. Therefore, finding the optimal warehouse in a limited service area with the help of method of radiation therapy or the ant algorithm method gives the same results.

In the paper, applying method of radiation therapy, we determined warehouse A, which is at Milyutenko street, 28, as most optimally located to all the supermarkets. Therefore, finding the optimal warehouse in a limited service area with the help of method of radiation therapy or the ant algorithm gives the same results. It is known that the capacity of warehouse A at Milyutenko street, 28, cannot satisfy the demand of all consumers. Hence, we find one more optimally located warehouse to the consumers by means of the ant colony algorithm. When calculating, the warehouse, which was previously found as an optimal one as well as the supermarkets, which it serves, are excluded. Such a procedure will be executed until the number of optimally located warehouses satisfy the demand of all the supermarkets.

As a result of the conducted calculations using the ant colony method, we discovered that three optimally located warehouses fully meet the demand of all the consumers. As shown in Table 3, these warehouses are at Milyutenko street, 28, Karbyshev street, 18B and Theodore Dreiser street, 11. The results of these calculations completely 
Table 3. Costs of delivery of goods depending on the location and number of warehouses in the logistics system

\begin{tabular}{|c|c|c|c|c|c|c|c|c|c|c|c|c|}
\hline & \multicolumn{5}{|c|}{ 1st iteration } & \multicolumn{4}{|c|}{ 2nd iteration } & \multicolumn{3}{|c|}{ 3rd iteration } \\
\hline & A & $\mathrm{B}$ & $\mathrm{C}$ & $\mathrm{D}$ & $\mathrm{E}$ & $\mathrm{B}$ & $\mathrm{C}$ & $\mathrm{D}$ & $\mathrm{E}$ & $\mathrm{B}$ & $\mathrm{C}$ & $\mathrm{E}$ \\
\hline \multicolumn{13}{|c|}{ Costs of delivery from the manufacturer to distribution centers } \\
\hline Distance $[\mathrm{km}]$ & 10 & 10 & 14 & 12 & 13 & 10 & 14 & 12 & 13 & 10 & 14 & 13 \\
\hline Weight of cargo $[\mathrm{t}]$ & 18.45 & 18.45 & 18.45 & 18.45 & 18.45 & 10.95 & 10.95 & 10.95 & 10.95 & 6.05 & 6.05 & 6.05 \\
\hline Work $[\mathrm{t} \cdot \mathrm{km}]$ & 184.50 & 184.50 & 258.30 & 221.40 & 239.85 & 109.50 & 153.30 & 131.40 & 142.35 & 60.50 & 84.70 & 78.65 \\
\hline $\begin{array}{l}\text { Work of } \\
\text { a refrigerator [year] }\end{array}$ & 0.40 & 0.40 & 0.56 & 0.48 & 0.52 & 0.40 & 0.56 & 0.48 & 0.52 & 0.40 & 0.56 & 0.52 \\
\hline $\begin{array}{l}\text { Fuel consumption } \\
\text { mileage }[1]\end{array}$ & 6.00 & 6.00 & 8.40 & 7.20 & 7.80 & 6.00 & 8.40 & 7.20 & 7.80 & 6.00 & 8.40 & 7.80 \\
\hline Fuel expense work [l] & 1.85 & 1.85 & 2.58 & 2.21 & 2.40 & 1.10 & 1.53 & 1.31 & 1.42 & 0.61 & 0.85 & 0.79 \\
\hline $\begin{array}{l}\text { Fuel consumption } \\
\text { of a refrigerator [1] }\end{array}$ & 1.60 & 1.60 & 2.24 & 1.92 & 2.08 & 1.60 & 2.24 & 1.92 & 2.08 & 1.60 & 2.24 & 2.08 \\
\hline Total fuel [l] & 9.45 & 9.45 & 13.22 & 11.33 & 12.28 & 8.70 & 12.17 & 10.43 & 11.30 & 8.21 & 11.49 & 10.67 \\
\hline $\begin{array}{l}\text { Loading/unloading } \\
\text { time [min] }\end{array}$ & 92 & 92 & 92 & 92 & 92 & 56 & 56 & 56 & 56 & 32 & 32 & 32 \\
\hline $\begin{array}{l}\text { Time of documents } \\
\text { processing [min] }\end{array}$ & 30 & 30 & 30 & 30 & 30 & 30 & 30 & 30 & 30 & 30 & 30 & 30 \\
\hline $\begin{array}{l}\text { Manoeuvring } \\
\text { time [min] }\end{array}$ & 16 & 16 & 16 & 16 & 16 & 16 & 16 & 16 & 16 & 16 & 16 & 16 \\
\hline $\begin{array}{l}\text { Rate of delivery } \\
\text { time [min] }\end{array}$ & 24 & 24 & 34 & 29 & 31 & 24 & 34 & 29 & 31 & 24 & 34 & 31 \\
\hline Total time spent $[\mathrm{h}]$ & 5.40 & 5.40 & 5.72 & 5.56 & 5.64 & 4.20 & 4.52 & 4.36 & 4.44 & 3.40 & 3.72 & 3.64 \\
\hline Fuel cost [UAH] & 208.73 & 208.73 & 292.23 & 250.48 & 271.35 & 192.16 & 269.02 & 230.59 & 249.81 & 181.33 & 253.86 & 235.73 \\
\hline Driver's cost [UAH] & 355.26 & 355.26 & 376.32 & 365.79 & 371.05 & 276.32 & 297.37 & 286.84 & 292.11 & 223.68 & 244.74 & 239.47 \\
\hline Total costs [UAH] & 564.00 & 564.00 & 668.54 & 616.27 & 642.41 & 468.48 & 566.39 & 517.43 & 541.91 & 405.01 & 498.60 & 475.20 \\
\hline \multicolumn{13}{|c|}{ Costs of delivery from distribution centers to supermarkets } \\
\hline Distance $[\mathrm{km}]$ & 33.1 & 35.5 & 33.2 & 33.4 & 35.6 & 30.1 & 22.5 & \begin{tabular}{|l|}
22.7 \\
\end{tabular} & 24.6 & 27.1 & 19.4 & 21.2 \\
\hline Weight of cargo $[\mathrm{t}]$ & 18.45 & 18.45 & 18.45 & 18.45 & 18.45 & 10.95 & 10.95 & 10.95 & 10.95 & 6.05 & 6.05 & 6.05 \\
\hline Work $[\mathrm{t} \cdot \mathrm{km}]$ & 327.22 & 376.61 & 311.34 & 310.59 & 342.25 & 130.05 & 117.66 & 139.52 & 114.53 & 83.29 & 69.98 & 74.49 \\
\hline $\begin{array}{l}\text { Work of } \\
\text { a refrigerator [year] }\end{array}$ & 1.32 & 1.42 & 1.33 & 1.34 & 1.42 & 1.20 & 0.90 & 0.91 & 0.98 & 1.08 & 0.78 & 0.85 \\
\hline $\begin{array}{l}\text { Fuel consumption } \\
\text { mileage [l] }\end{array}$ & 9.93 & 10.65 & 9.96 & 10.02 & 10.68 & 9.03 & 6.75 & 6.81 & 7.38 & 8.13 & 5.82 & 6.36 \\
\hline Fuel expense work [1] & 3.27 & 3.77 & 3.11 & 3.11 & 3.42 & 1.30 & 1.18 & 1.40 & 1.15 & 0.83 & 0.70 & 0.74 \\
\hline $\begin{array}{l}\text { Fuel consumption of } \\
\text { a refrigerator [l] }\end{array}$ & 5.30 & 5.68 & 5.31 & 5.34 & 5.70 & 4.82 & 3.60 & 3.63 & 3.94 & 4.34 & 3.10 & 3.39 \\
\hline Total fuel [1] & 18.50 & 20.10 & 18.39 & 18.47 & 19.80 & 15.15 & 11.53 & 11.84 & 12.46 & 13.30 & 9.62 & 10.50 \\
\hline $\begin{array}{l}\text { Loading/unloading } \\
\text { time [min] }\end{array}$ & 92 & 92 & 92 & 92 & 92 & 56 & 56 & 56 & 56 & 32 & 32 & 32 \\
\hline $\begin{array}{l}\text { Time of documents } \\
\text { processing [min] }\end{array}$ & 240 & 240 & 240 & 240 & 240 & 150 & 150 & 150 & 150 & 75 & 75 & 75 \\
\hline $\begin{array}{l}\text { Manoeuvring } \\
\text { time [min] }\end{array}$ & 128 & 128 & 128 & 128 & 128 & 80 & 80 & 80 & 80 & 40 & 40 & 40 \\
\hline $\begin{array}{l}\text { Rate of delivery } \\
\text { time [min] }\end{array}$ & 79 & 85 & 80 & 80 & 85 & 72 & 54 & 54 & 59 & 65 & 47 & 51 \\
\hline Total time spent $[\mathrm{h}]$ & 8.99 & 9.09 & 8.99 & 9.00 & 9.09 & 5.97 & 5.67 & 5.67 & 5.75 & 3.53 & 3.23 & 3.30 \\
\hline Fuel cost [UAH] & 408.81 & 444.12 & 406.32 & 408.18 & 437.55 & 334.74 & 254.74 & 261.60 & 275.39 & 293.91 & 212.69 & 231.98 \\
\hline Driver's cost [UAH] & 591.49 & 597.81 & 591.75 & 592.28 & 598.07 & 392.81 & 372.81 & 373.33 & 378.33 & 232.50 & 212.24 & 216.97 \\
\hline Total costs [UAH] & 1000.30 & 1041.93 & 998.07 & 1000.47 & 1035.62 & 727.54 & 627.54 & 634.94 & 653.73 & 526.41 & 424.94 & 448.96 \\
\hline Total costs [UAH] & 1564.30 & 1605.93 & 1666.62 & 1616.74 & 1678.02 & 1196.02 & 1193.94 & 1152.37 & 1195.64 & 931.42 & 923.52 & 924.16 \\
\hline
\end{tabular}


coincide with the results of the previous calculations when applying the proposed method.

As the comparative analysis shows, finding optimally located warehouses through the method for optimal planning of radiation therapy of malignant tumors Klepper (2009) and the ant-colony method Dorigo et al. (1996) and Shtovba (2003) produces the same result. That testifies the accuracy of the proposed method for finding optimally located service points, which is based on the method for optimal planning of radiation therapy of malignant tumors.

It is known that in the general case, the presence of several (more than 1) distributed centers increases the amount of total costs in the logistics system than the presence of one distributed center. This may be due to the fact that the cost of maintaining such distribution centers (warehouses) may exceed the other costs. However, often the capacity of the distributed center is limited, so there is a need for increased such centers. Such a task was considered in Section 3 when finding the optimal location warehouses by the radiation therapy method.

In addition, the need to increase the expansion can occur when there is a need for an expanded product market for the manufacturer (increasing the number of customers), while the capacity of one distributed center is limited. This means that there are sales losses.

Let us consider in this logistical problem the system of the composition of the manufacturer of products, 5 distributed centers and 15 supermarkets. The solution to this problem is to find the number of warehouses in the logistics system, in which the costs of maintaining the entire system were minimal. It is known that the use of each warehouse is characterized by the size of the total costs, which include: (1) the cost of delivery of goods from the manufacturer; (2) the cost of delivery of goods from the distributed center to the end user and (3) the costs associated with storage of goods and warehouse operation and other costs. In determining the costs of delivering goods to warehouses and warehouses to supermarkets, information was taken into account about the distance between the enterprise-producer of the product and the distribution center, the weight of the goods transported and the time of delivery of the goods, which affects the amount of remuneration of the driver. Costs associated with the storage of goods in warehouses were determined by the size of stocks of goods in warehouses that need to be kept to ensure uninterrupted supply of goods to end users. Operating costs take into account the costs of storing storage facilities. Wages of staff and other non-constant costs are included in the group of other expenses.

Losses from lost sales are determined by the number of supermarkets that cannot be serviced in case of insufficient quantity of warehouse in the logistic system and other reasons. Among them: the capacity of the distribution center, which does not allow to increase the volume of goods, the number of points of delivery of goods in one car per day cannot exceed 15 (data for the city of Kyiv) and other reasons. The amount of losses is expressed in terms of the quantity of goods that the producer of the enterprise cannot deliver to potential buyers (supermarkets).

For such a task it is important to find the number of warehouses in the logistics distribution system, the total cost at which, were the smallest. To find this number of warehouses, we use the information on the cost of delivery of goods and the payment of drivers, given in Table 3. In addition, we take into account operating costs, costs associated with storage of products, costs from market losses and other costs listed in Table 4.

According to Table 4, operating expenses include the cost of maintaining a warehouse (payment of utility bills). Other costs include, in particular, the salary of accompanying staff. The costs of lost sales are determined by the amount of losses received by the producer of the product from the impossibility of meeting the needs of all consumers.

As can be seen from Table 4, in the presence of a single distribution center with sufficient capacity, the inclusion of costs without loss from sales is sufficient to provide all consumers 22566 UAH (Figure 4). Given the situation with market growth, that is, sales losses, calculations show that the total cost is minimal in the case of two distribution centers (Figure 5).

According to the received calculations, taking into account the size of lost sales, the optimal number of warehouses is 2, which can be seen in Figure 5. The total cost of such placement will be 35856 UAH. A greater number of warehouses are economically disadvantageous, with a significant increase in total costs for 4 or more warehouses in the system. This suggests that the size of lost sales for placed 3, 4 and 5 warehouses does not actually change, and the cost of their maintenance is only increasing.

Thus, the calculations made indicate that the value of costs can vary from the needs and objectives set by the manufacturer. This determines the choice of a distributed logistics system model, which minimizes the cost of delivering goods to consumers.

The calculations display the advantages of the proposed method for finding the optimal number and optimal capacity of service points (warehouses), being based on the method for optimal planning of radiation therapy of malignant tumors. Besides, these advantages have to be the possibilities of solving the appropriate problems of optimization of high dimensionality, high accuracy of results, speed of calculations, possibility of applying the proposed method to solve this kind of problems that describe different processes of physical nature.

As this paper examines a pioneering developed method for optimizing the location of warehouses to customers, which is based on the method for optimal planning of radiation therapy of malignant tumors, there is a need to carry out further experiments in order to determine the bounds of its application and possibilities of its refinement. 
Table 4. Calculation of costs for a logistics system with different number of distribution centers

\begin{tabular}{|c|c|c|c|c|c|c|c|c|}
\hline $\begin{array}{c}\text { Number of } \\
\text { warehouses }\end{array}$ & $\begin{array}{c}\text { Costs for delivery } \\
\text { to warehouses } \\
{[\mathrm{UAH}]}\end{array}$ & $\begin{array}{c}\text { Costs for delivery } \\
\text { to supermarkets } \\
{[\mathrm{UAH}]}\end{array}$ & $\begin{array}{c}\text { Operating } \\
\text { costs } \\
{[\mathrm{UAH}]}\end{array}$ & $\begin{array}{c}\text { Storage } \\
\text { costs } \\
{[\mathrm{UAH}]}\end{array}$ & $\begin{array}{c}\text { Other } \\
\text { costs } \\
{[\mathrm{UAH}]}\end{array}$ & $\begin{array}{c}\text { Total cost } \\
\text { without lost } \\
\text { sales [UAH] }\end{array}$ & $\begin{array}{c}\text { Lost sales } \\
{[\mathrm{UAH}]}\end{array}$ & $\begin{array}{c}\text { Total cost } \\
{[\mathrm{UAH}]}\end{array}$ \\
\hline 1 & 5640 & 10003 & 2310 & 1413 & 3200 & 22566 & 15000 & 37566 \\
\hline 2 & 11280 & 6349 & 4158 & 2669 & 6400 & 30856 & 5000 & 35856 \\
\hline 3 & 17443 & 4249 & 5240 & 3454 & 9600 & 39986 & 500 & 40486 \\
\hline 4 & 23867 & 7275 & 9240 & 4710 & 12800 & 57892 & 500 & 58392 \\
\hline 5 & 30552 & 10599 & 11550 & 5966 & 16000 & 74667 & 500 & 75167 \\
\hline
\end{tabular}

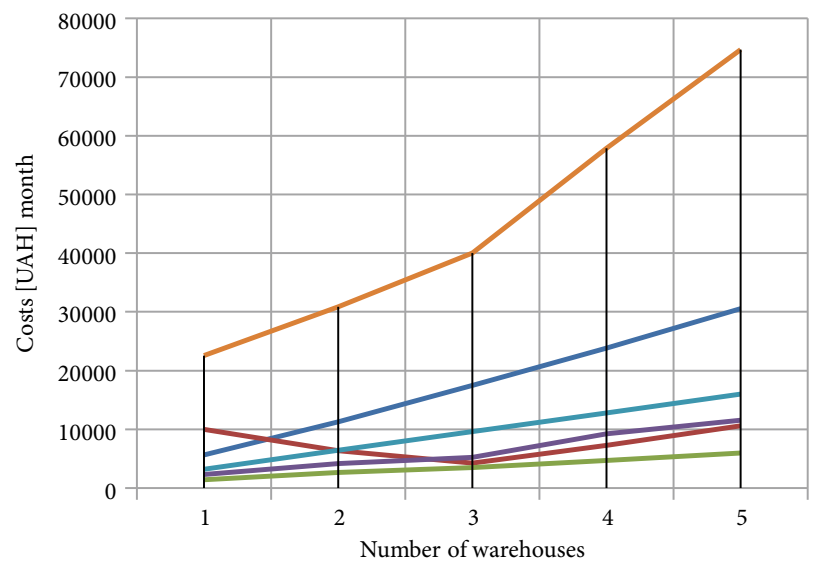

\begin{tabular}{ll}
\hline Costs for delivery to warehouses & Operating costs \\
Costs for delivery to supermarkets & Other costs \\
Storage costs & Total costs
\end{tabular}

Figure 4. Costs for maintaining the logistics system without the account of lost sales

\section{Conclusions}

The paper suggests a method for determining the optimal location of service points (warehouses) based on the method for optimal planning of radiation therapy of malignant tumors. The method developed in the paper enabled to choose from all existing warehouses those that are the most optimally located to consumers. This method enabled to identify the location of the most optimal number of warehouses taking into account their capacity for the required volume of freight transportation and distance from warehouses to consumers.

The results of the study coincide with the results obtained by using the method of ant algorithm.

The proposed method of finding the optimal location of warehouses enables to significantly minimize the cost of delivering goods from a producer to a consumer.

\section{References}

Dorigo, M.; Maniezzo V.; Colorni, A. 1996. Ant system: optimization by a colony of cooperating agents, IEEE Transactions on Systems, Man, and Cybernetics, Part B (Cybernetics) 26(1): 29-41. https://doi.org/10.1109/3477.484436

Drezner, T. 2014. A review of competitive facility location in the plane, Logistics Research 7: 114.

https://doi.org/10.1007/s12159-014-0114-z

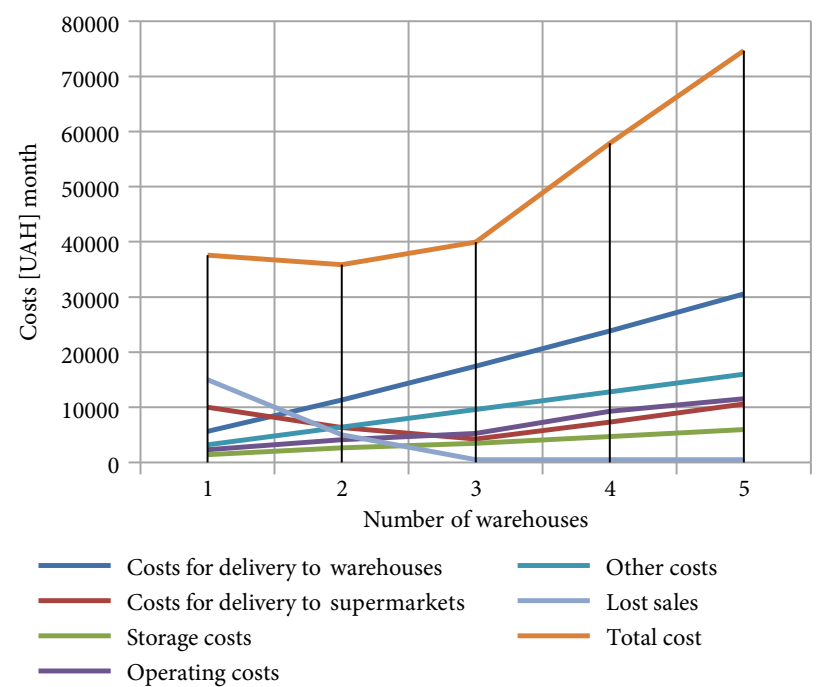

Figure 5. Costs for maintaining the logistics system with the account of lost sales

Grankina, N. A. 2014. Ob odnoj modeli zadachi optimizacii razmeshheniya i polya dejstviya konechnogo chisla istochnikov v nepreryvnoj srede, v Sbornik materialov IX Mezhdunarodnoj nauchnoj konferencii studentov i molodyh uchenyh "Nauka i obrazovanie - 2014", 11 aprelya 2014 g., Astana, Kazahstan, 2311-2314. (in Russian).

Griffin, P. M.; Scherrer, C. R.; Swann, J. L. 2008. Optimization of community health center locations and service offerings with statistical need estimation, IIE Transactions 40(9): 880-892. https://doi.org/10.1080/07408170802165864

Gu, W.; Wang, X.; McGregor, S. E. 2010. Optimization of preventive health care facility locations, International Journal of Health Geographics 9: 17.

https://doi.org/10.1186/1476-072X-9-17

Kazakov, A. L.; Lempert, A. A. 2011. Ob odnom podhode k resheniyu zadach optimizacii, voznikayushhih v transportnoj logistike, Avtomatika i telemehanika 7: 50-57. (in Russian).

Kazakov, A. L.; Pospelov, A. M. 2008. Opredelenie optimal'nogo mestonahozhdeniya bazovogo kontejnernogo terminala, Transport Urala 2: 50-57. (in Russian).

Klepper, L. Ya. 2009. Opredelenie polya dejstviya konechnogo chisla istochnikov v nepreryvnoj srede, Jekonomika $i$ matematicheskie metody 45(2): 113-119. (in Russian).

Melo, M. T.; Nickel, S.; Saldanha da Gama, F. 2006. Dynamic multi-commodity capacitated facility location: a mathematical modeling framework for strategic supply chain planning, Computers \& Operations Research 33(1): 181-208. https://doi.org/10.1016/j.cor.2004.07.005 
MSP. 2017. Rozrahunok normy tryvalosti robochogo chasu na 2017 rik. Ministerstvo social'noi' polityky (MSP) Ukrai'ny. Available from Internet:

https://www.msp.gov.ua/news/8632.html (in Ukrainian).

Shtovba, S. D. 2003. Murav'inye algoritmy, Exponenta Pro. Matematika v prilozheniyah 4: 70-75. (in Russian).

Sonmez, A. D.; Lim, G. J. 2012. A decomposition approach for facility location and relocation problem with uncertain number of future facilities, European Journal of Operational Research 218(2): 327-338. https://doi.org/10.1016/j.ejor.2011.10.028

Sun, M. 2006. Solving the uncapacitated facility location problem using tabu search, Computers \& Operations Research 33(9): 2563-2589. https://doi.org/10.1016/j.cor.2005.07.014

Taji, T.; Tanigawa, S.-I.; Kamiyama, N.; Katoh, N.; Takizawa, A. 2008. Finding an optimal location of line facility using evolutionary algorithm and integer program, Journal of Computational Science and Technology 2(3): 362-370. https://doi.org/10.1299/jcst.2.362

Ua.trud.com. 2017. Obzor statistiki zarplat professii Voditel' firmy $v$ Kieve. Available from Internet: https://ua.trud.com/kiev/salary/12/76922.html (in Russian).

VRU. 1987. Jedyni normy chasu na perevezennya vantazhiv avtomobil'nym transportom $i$ vidryadni rozcinky dlya oplaty praci vodii'v. Postanovlenie Goskomtruda SSSR i Sekretariata VCSPS No 153/6-142. Zakonodavstvo Ukrainy, Verhovna Rada Ukrai'ny (VRU). Available from Internet: https://zakon3.rada.gov.ua/laws/show/v0142400-87 (in Ukrainian and Russian). 